
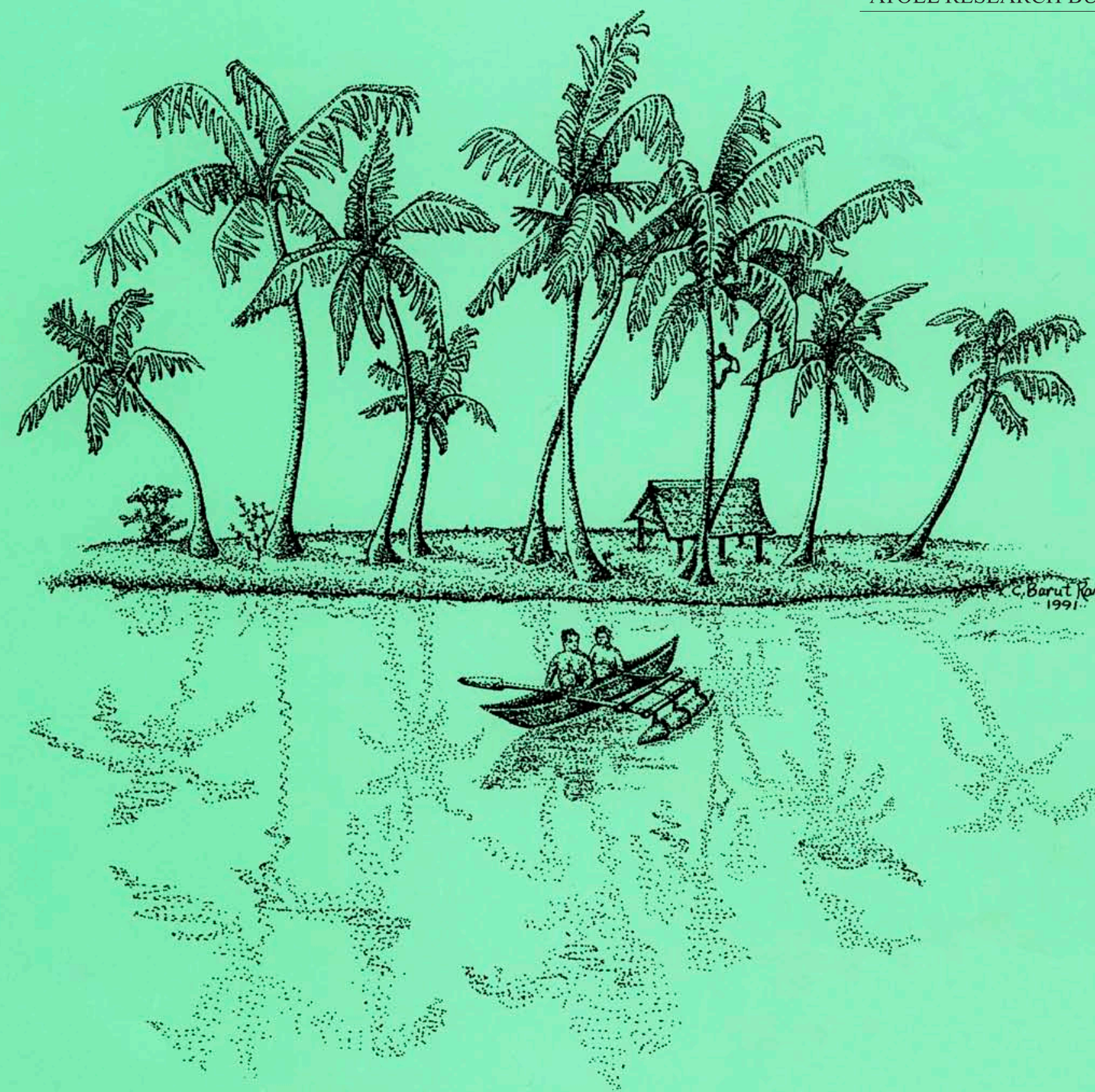

COMMUNITY STRUCTURE OF SCLERACTINIAN

CORALS OUTSIDE PROTECTED AREAS IN COZUMEL ISLAND, MEXICO

ATOLL

Héctor Reyes-Bonilla, Marinés Millet-Encalada, and Lorenzo Álvarez-Filip

RESEARCH 


\section{COMMUNITY STRUCTURE OF SCLERACTINIAN CORALS OUTSIDE PROTECTED AREAS IN COZUMEL ISLAND, MEXICO}

Héctor Reyes-Bonilla, Marinés Millet-Encalada, and Lorenzo Álvarez-Filip

Atoll Research Bulletin No. 601 • 6 January 2014

Smithsonian Institution

Scholarly Press 
All statements made in papers published in the Atoll Research Bulletin are the sole responsibility of the authors and do not necessarily represent the views of the Smithsonian Institution or of the editors of the Bulletin. Articles submitted for publication in the Atoll Research Bulletin should be original papers and must be made available by authors for open access publication. Manuscripts should be consistent with the "Author Formatting Guidelines for Publication in the Atoll Research Bulletin." All submissions to the Bulletin are peer reviewed and, after revision, are evaluated prior to acceptance and publication through the publisher's open access portal, Open SI (http://opensi.si.edu).

Published by SMITHSONIAN INSTITUTION SCHOLARLY PRESS

P.O. Box 37012, MRC 957

Washington, D.C. 20013-7012

www.scholarlypress.si.edu

The rights to all text and images in this publication are owned either by the contributing authors or third parties. Fair use of materials is permitted for personal, educational, or noncommercial purposes. Users must cite author and source of content, must not alter or modify the content, and must comply with all other terms or restrictions that may be applicable. Users are responsible for securing permission from a rights holder for any other use.

ISSN: 0077-5630 (online) 


\title{
COMMUNITY STRUCTURE OF SCLERACTINIAN CORALS OUTSIDE PROTECTED AREAS IN COZUMEL ISLAND, MEXICO
}

\author{
HÉCTOR REYES-BONILLA ${ }^{1}$, MARINÉS MILLET-ENCALADA ${ }^{1,2}$ and LORENZO ÁLVAREZ-FILIP ${ }^{3}$
}

\begin{abstract}
Cozumel Island is of paramount importance for Mexico, because of the good state of its marine ecosystems, and as a touristic spot that attracts thousands of divers every day. Most studies about the local reefs have been devoted to those formations located inside the Cozumel Reefs National Park, in the southwest side of the island; however there are other important reefs that have received little attention. The objective of this paper was to conduct an analysis of zooxanthellate coral community structure in six sites of the eastern and northwestern coasts of Cozumel, and to compare them with the status of the reefs already under federal management. The results showed that there were no significant differences in coral cover, diversity, evenness and taxonomic distinctness of reefs inside and outside the protected area, a pattern that differed from that reported in previous studies. The homogeneity in the ecological structure may have resulted from the combined effects of differential human pressure (high in PNAC reefs, low outside of the park), and the high coral mortality caused in all areas by category 5 hurricanes "Emily" and "Wilma" in 2005. Considering these findings, we suggest that local authorities must allocate more effort dedicated to the conservation of reefs in the eastern coast of the island, as some of them (especially Hanan) are very well developed and house species of particular interest such as Acropora spp.
\end{abstract}

\section{INTRODUCTION}

The western Caribbean Sea is notable for the coral reefs found off the coasts of Mexico, Belize, Honduras, and Guatemala, which together form the Mesoamerican Barrier Reef System, the second largest in the world after the Great Barrier Reef of Australia (Rützler and Macintyre, 1982; AlmadaVillela et al., 2003). In Mexico, the formation extends almost continuously for $400 \mathrm{~km}$ along the coast, and in its northern part is located at the island of Cozumel, in the state of Quintana Roo. This area is renowned for its high diversity of species and the excellent development of its coral formations (Jordán, 1988; Muckelbauer, 1990, Gutiérrez et al., 1995), and for that reason the reefs between the Paraíso and Punta Chiqueros (20 $29^{\prime}$ and $20^{\circ} 14^{\prime} \mathrm{N}$, and $86^{\circ} 53^{\prime}$ and $87^{\circ} 03^{\prime} \mathrm{W}$ ) were designated part of a protected area in 1996: the Cozumel Reefs National Park (PNAC; Figure 1). These formations are of great importance for Mexico, both biologically and socioeconomically (Arriaga-Carrera et al., 1998; Spalding, 2004). They support more than 1,500 marine species, among them various endemic species and others protected by the Mexican federal government (Anonymous, 1996). Tourism is the main economic activity on the island, as Cozumel is a key destination for snorkeling and scuba divers, and is considered among the best spots for this activity in the world (Ortiz-Lozano et al., 2005).

Historically, most scientific and monitoring studies on the island have been carried out along the southwestern portion, since the reef systems in that area are well developed and can be easily accessed. Several authors have described the coral and fish communities from the ecological and geological viewpoint, and have also evaluated the damages caused by intense perturbations such as hurricanes "Gilbert" in 1987, and "Wilma" and "Emily" in 2005 (Fenner, 1988; Jordán, 1988; Fenner, 1991; Chávez, 1997; Muñoz-Chaguín, 1997; Díaz Ruiz et al., 1998; Álvarez-Filip and Gil, 2006; Millet-Encalada et al.,

\footnotetext{
${ }^{1}$ Universidad Autónoma de Baja California Sur. Departamento Académico de Biología Marina. Apartado postal 19B, CP 23080. La Paz, Baja California Sur. México.

2 Parque Nacional Arrecifes de Cozumel. Calle 4 Norte \#356. C.P. 77600. Cozumel, Quintana Roo, México.

${ }^{3}$ University of East Anglia. Centre for Ecology, Evolution and Conservation, Norwich, United Kingdom. NR4 7TJ.
} 
2007; Alvarez-Filip et al 2009), as well as the subsequent recovery of the ecosystem. In contrast, studies undertaken on reefs located outside the park are scarce. Jordan (1989) identified specific sites on the eastern side of the island as having optimal conditions for the growth of corals (i.e. high topographic relief and low levels of sedimentation), while Muckelbauer (1990) and García-Beltrán and Loreto-Viruel (1997) described the topography of the platform and characterized the benthic communities of fish along the insular shelf edge. More recently, Steneck et al. (2003) described microatolls (mushroom-shaped structures) and algal ridges, a feature unique in the western Caribbean.

The understanding of the coral communities around Cozumel Island is fundamental to the development of management tools devoted to buffer the intense pressure resulting from activities of anthropogenic origin that could promote changes in their composition, but even so, very little about the composition of reefs outside the PNAC is known. The objective of this study is therefore to undertake a detailed analysis of the community structure of reefs situated along the eastern and northwestern edges of Cozumel, and to compare their current state with well described reefs within the national park.

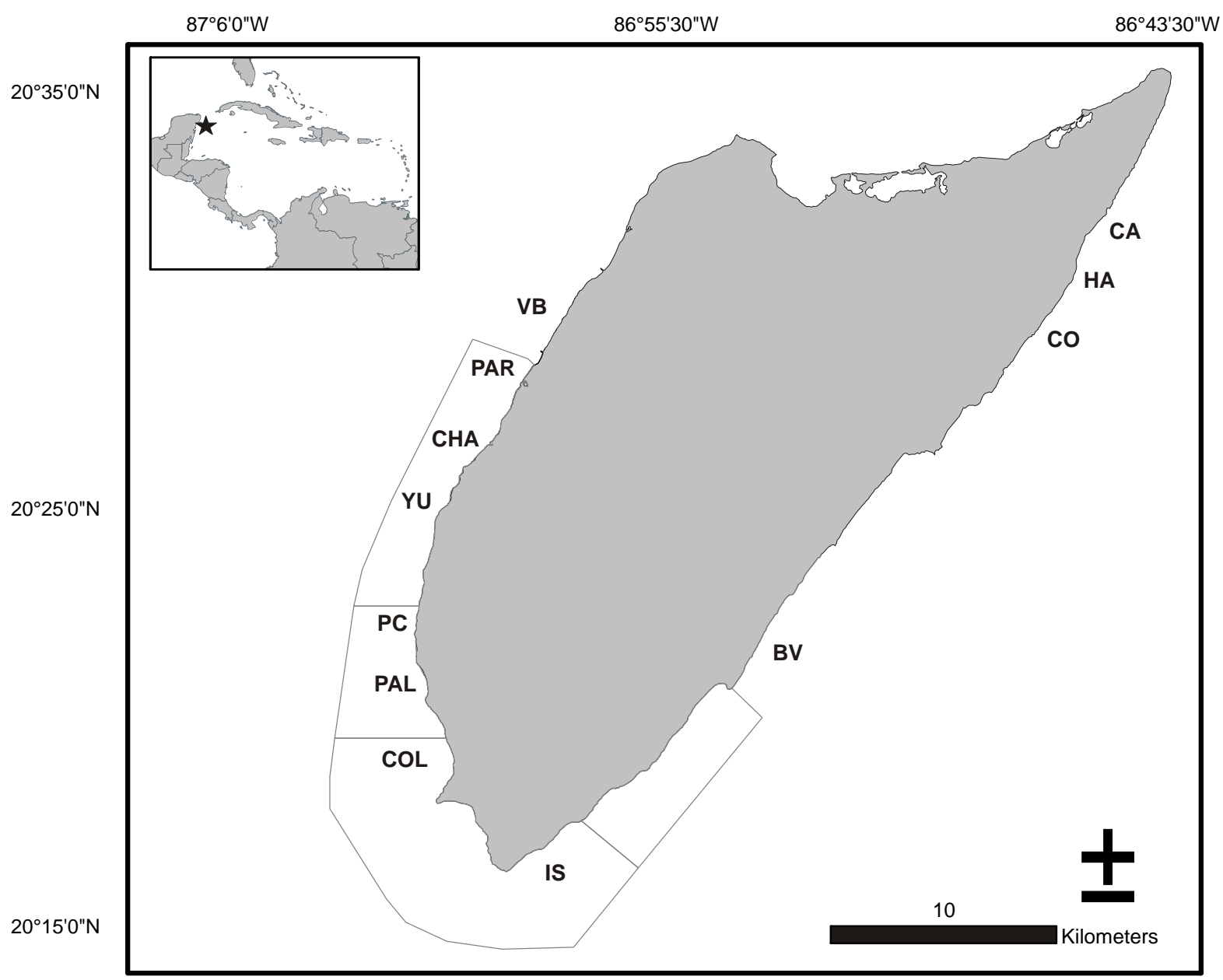

Figure 1. Study area. Key: $\mathrm{PAR}=$ Paraíso, $\mathrm{CHA}=$ Chankana' $\mathrm{ab}, \mathrm{YU}=\mathrm{Yucab}, \mathrm{PC}=$ Paso del Cedral, $\mathrm{PAL}=$ Palancar, $\mathrm{COL}=$ Colombia, $\mathrm{IS}=$ Islote, $\mathrm{VB}=$ Villa Blanca, $\mathrm{BV}=$ Buenavista, $\mathrm{HA}=$ Hanan, $\mathrm{CO}=\mathrm{Cocos}$, $\mathrm{CA}=\mathrm{El}$ Castillo. The line demarks the limits of Cozumel Reefs National Park (PNAC). 


\section{METHODS}

\section{Study Area}

The Island of Cozumel is located $22 \mathrm{~km}$ off the eastern coast of the Yucatán Peninsula, Mexico, within the coordinates $20^{\circ} 35^{\prime} 22^{\prime \prime} \mathrm{N}$ and $20^{\circ} 16^{\prime} 11^{\prime \prime} \mathrm{N}$, and $86^{\circ} 43^{\prime} 46^{\prime \prime} \mathrm{W}$ and $86^{\circ} 59^{\prime} 26^{\prime \prime} \mathrm{W}$ (Figure 1). The island is oval-shaped with the major axis orientated in a southwest-northeast direction, and is approximately $46 \mathrm{~km}$ in length, with the minor axis of $16 \mathrm{~km}$ in length at the widest point (Fenner, 1988; Jordán, 1988).

The marine environment of Cozumel is largely characterized by the permanently flowing Yucatán Channel current, which travels between the mainland and the island with net movement from south to north. The velocity of this current is usually between one and three knots, but may reach up to four knots in summer (Cetina et al., 2006). The patterns of circulation are very important for reef formation, extension and development, and for the propagation of coral larvae (Jordán-Dahlgren and RodríguezMartínez, 2003). In addition, on the western coast of the island counter-currents have been recorded flowing towards the south and south-southwest, particularly in the vicinity of Paraíso and Chankana'ab (Muckelbauer, 1990).

A pronounced and distant ridge extends approximately $2 \mathrm{~km}$ along the eastern coast of Cozumel, reaches $50 \mathrm{~m}$ in depth, while the northern edge of the island has a smooth sloping plain where the platform extends for more than $50 \mathrm{~km}$. The western and southwestern zones show intermediate characteristics, with a slight inclination of the bottom in shallow waters constituted by a short platform and pronounced fall or wall at $20 \mathrm{~m}$ in depth (Jordán, 1989; Muckelbauer, 1990).

\section{Field Work}

The community structure of scleractinian corals was analyzed during November 2005 in five reefs situated outside the Marine Protected Area, on the eastern and northwestern sides of the Island of Cozumel. The study sites were Villa Blanca, Buenavista, El Castillo, Hanan and Los Cocos (Figure 1).

To analyze composition and abundance of coral we used the intercept point technique, as it provides precise information and represents the standard method for studying coral assemblages throughout the Mesoamerican Reef (Almada-Villela et al., 2003). On each reef, four to six $30 \mathrm{~m}$-long transects $(\mathrm{N}=27)$ were placed randomly in a direction parallel to the coast, and at depths between 5 and $20 \mathrm{~m}$. Coral cover (total and for each species) was determined by counting the number of corals found directly underneath points marked each $25 \mathrm{~cm}$ along the transect (120 points per survey unit; 3.240 total sampling points). Corals were identified in situ to species level using criteria from Humann (2002) and Veron (2000), and in some cases, a photograph of the colony was taken for confirmation. No specimens were collected.

\section{Data Analysis}

On the basis of the information for each census, species richness was determined by direct count of the taxa present in the survey, while coral cover (percentage of the bottom) was estimated as the number of points where each species was present in a transect, divided between 120 total points. Later, the Shannon-Wiener diversity index was calculated $\left(\mathrm{H}^{\prime}\right.$, using $\left.\log 10\right)$ along with the Pielou uniformity index $\left(\mathrm{J}^{\prime}\right)$, and taxonomic distinctness $\left(\Delta^{*}\right)$; the latter is a tool that allows for the evaluation of diversity considering richness, abundance and the distance between pairs of individuals measured along a Linnean tree based on the taxonomic classification of the group, in this case, the one presented by Beltrán-Torres and Carricart-Ganivet (1999). For the calculation we used six levels (class, subclass, order, family, genus and species), assigning default values provided by the program PRIMER 6.0.

To detect patterns in community composition, resemblance among transects was estimated with Euclidian distance (Clarke and Gorley, 2006), and from the general dissimilarity matrix, a non-metric multidimensional scaling (nMDS) was run. This is a technique that constructs a graph in multiple dimensions (usually two or three), expressing the similitude between sampling units on the basis of the 
type of species present and their abundances. The sites are represented spatially through a relative distance and tend to group themselves together with those that most closely resemble themselves. The precision of this analysis is evaluated by the level of stress obtained: the lower the value, the clearer the separation between groups with distinctive characteristics (Clarke and Gorley, 2006).

Finally, the values for all ecological indices were compared between reefs with one-way analyses of variance, and the Student t- test was used to compare the obtained values with those from seven localities inside the PNAC (information taken from Millet-Encalada et al., 2007). Prior to this, normality and homogeneity of variance were assessed using Kolmogorov-Smirnov and Levene tests (Sokal and Rohlf, 1995). Data groups which did not meet these assumptions were subjected to Kruskal-Wallis analyses to determine if differences occurred inside and outside the protected area. As part of the examinations, post hoc Tukey (parametric) and Kruskal-Wallis (non-parametric) tests were carried out to detect the origin of the differences among treatments, depending on the case (Zar, 2009).

\section{RESULTS}

\section{Coral composition}

In the study area, 20 species from 9 families and 12 genera were found, with Hanan (northwest Cozumel) having the highest richness (18 species) and Villa Blanca (northeast coast of the island) the least with only 7 (Table 1). The corals Agaricia agaricites, Siderastrea siderea, Porites astreoides, and Montastraea cavernosa were the most abundant (Table 1) and most frequently found (Figure 2), as they appeared in all reefs and occurred in $25 \%$ to $90 \%$ of the transects. The four cited species were fundamental for reef building as they constituted $66 \%$ of the total coral cover (Figure 3). Of them, Agaricia agaricites was the dominant with an average cover of almost 3\% of the bottom, followed by Porites astreoides and Siderastrea siderea. The remaining corals were observed in fewer localities and individually represented less than 1\% cover; in fact, species such as Colpophyllia natans, Acropora palmata and Agaricia tenuifolia were observed in only one reef (Table 1).

Table 1. Scleractinian coral cover (in percentage), per location and in total (average \pm standard error). Key for reefs: $\mathrm{VB}=$ Villa Blanca; $\mathrm{CA}=\mathrm{El}$ Castillo; $\mathrm{HA}=\mathrm{Hanan}$; $\mathrm{CO}=\mathrm{Cocos}$; $\mathrm{BV}=$ Buenavista .

\begin{tabular}{|c|c|c|c|c|c|c|}
\hline & VB & $\mathbf{C A}$ & HA & $\mathrm{CO}$ & BV & Average \\
\hline Agaricia agaricites & 0.69 & 1.04 & 4.5 & 3.19 & 2.78 & $2.47 \pm 0.35$ \\
\hline Porites astreoides & 0.69 & 2.92 & 2.83 & 1.39 & 1.94 & $1.85 \pm 0.22$ \\
\hline Siderastrea siderea & 1.11 & 2.08 & 1.17 & 3.61 & 0.56 & $1.70 \pm 0.38$ \\
\hline Montastraea cavernosa & 0.69 & 0.21 & 2.67 & 1.11 & 0.28 & $0.99 \pm 0.21$ \\
\hline Montastraea faveolata & & & 0.33 & & 3.06 & $0.74 \pm 0.38$ \\
\hline Diploria clivosa & & 2.08 & 0.5 & 1.11 & & $0.65 \pm 0.24$ \\
\hline Diploria strigosa & & 0.21 & 0.5 & 2.08 & & $0.59 \pm 0.31$ \\
\hline Montastraea annularis & & & 0.33 & & 1.81 & $0.46 \pm 0.29$ \\
\hline Porites porites & & 0.21 & 1.33 & 0.28 & 0.28 & $0.40 \pm 0.14$ \\
\hline Colpophyllia natans & & & 1 & & & $0.19 \pm 0.13$ \\
\hline Porites colonensis & & 0.21 & 0.17 & 0.42 & 0.14 & $0.19 \pm 0.07$ \\
\hline Madracis decactis & 0.14 & & & & 0.56 & $0.15 \pm 0.08$ \\
\hline Stephanocoenia intersepta & 0.42 & & 0.17 & & & $0.12 \pm 0.06$ \\
\hline Dichocoenia stokesi & & & & 0.56 & & $0.12 \pm 0.07$ \\
\hline Meandrina meandrites & & & 0.17 & & 0.28 & $0.09 \pm 0.05$ \\
\hline Diploria labyrinthiformis & 0.28 & & 0.17 & & & $0.09 \pm 0.07$ \\
\hline Acropora palmata & & & 0.5 & & & $0.09 \pm 0.09$ \\
\hline Isophyllia sinuosa & & & 0.33 & & & $0.06 \pm 0.04$ \\
\hline Siderastrea radians & & & 0.17 & & & $0.03 \pm 0.03$ \\
\hline Agaricia tenuifolia & & & 0.17 & & & $0.03 \pm 0.03$ \\
\hline Total cover per site & 4.02 & 8.96 & 17.01 & 13.75 & 11.69 & $11.02 \pm 1.07$ \\
\hline Richness & 7 & 8 & 18 & 9 & 10 & \\
\hline Depth (m) & $5.30 \pm 0.01$ & $5.71 \pm 0.08$ & $9.33 \pm 0.26$ & $8.20 \pm 0.08$ & $20.10 \pm 0.10$ & \\
\hline
\end{tabular}




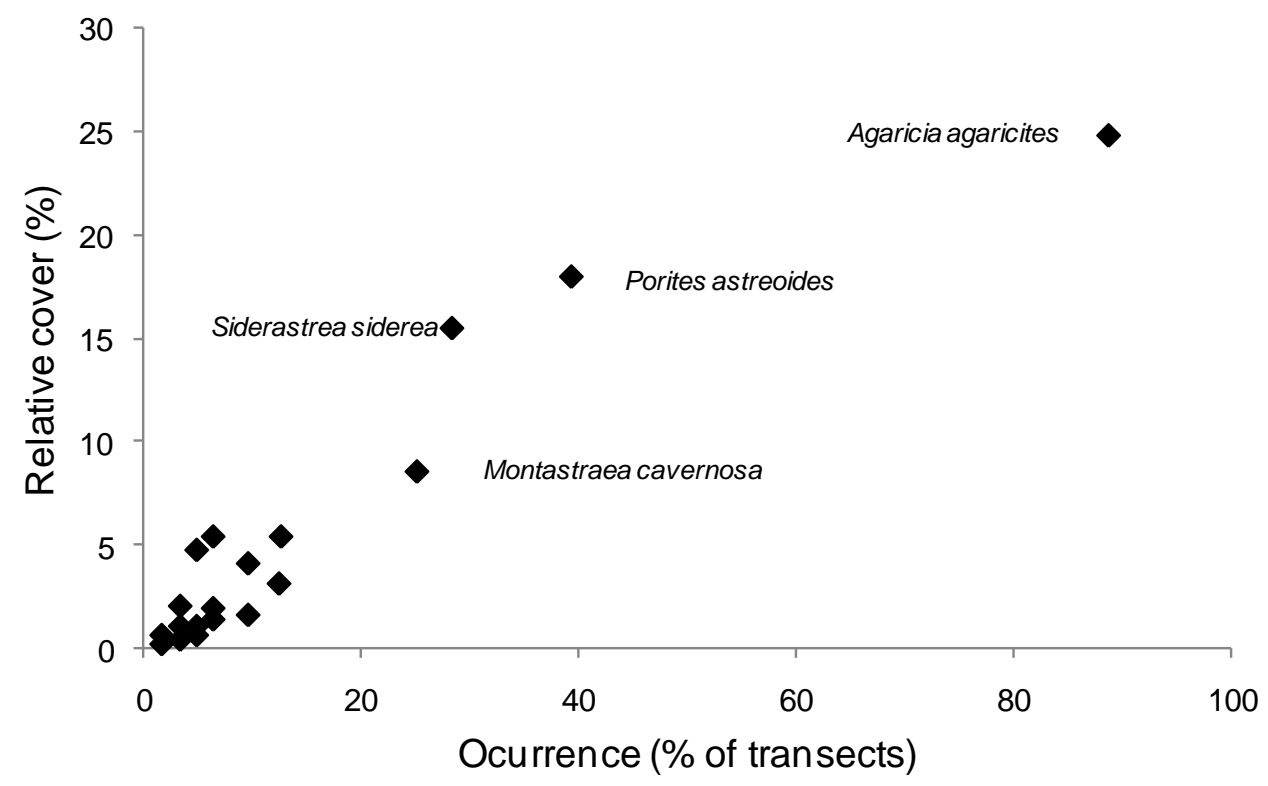

Figure 2. Relationship between relative occurrence and coral cover in reefs located outside PNAC, remarking the four most abundant scleractinian species.

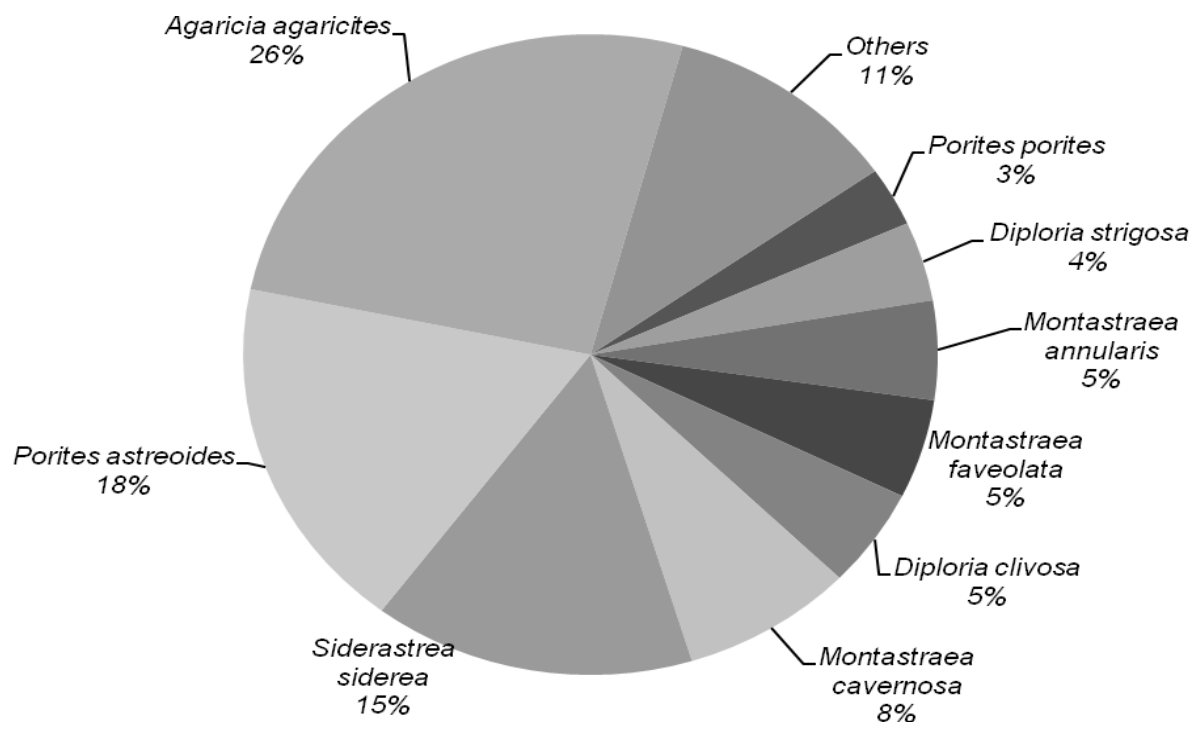

Figure 3. Relative cover (out of 100\%) of corals from reefs located outside PNAC.

\section{Community Structure}

The total cover found on the reefs located outside the PNAC was $11.02 \pm 1.07 \%$ and there were statistical differences between sites $\left(\mathrm{F}_{4,22}=11.229, p<0.001\right.$; Figure 4). Tukey's test indicated Villa Blanca had significantly less coral cover than all other sites except El Castillo, which was also significantly different from Hanan. 

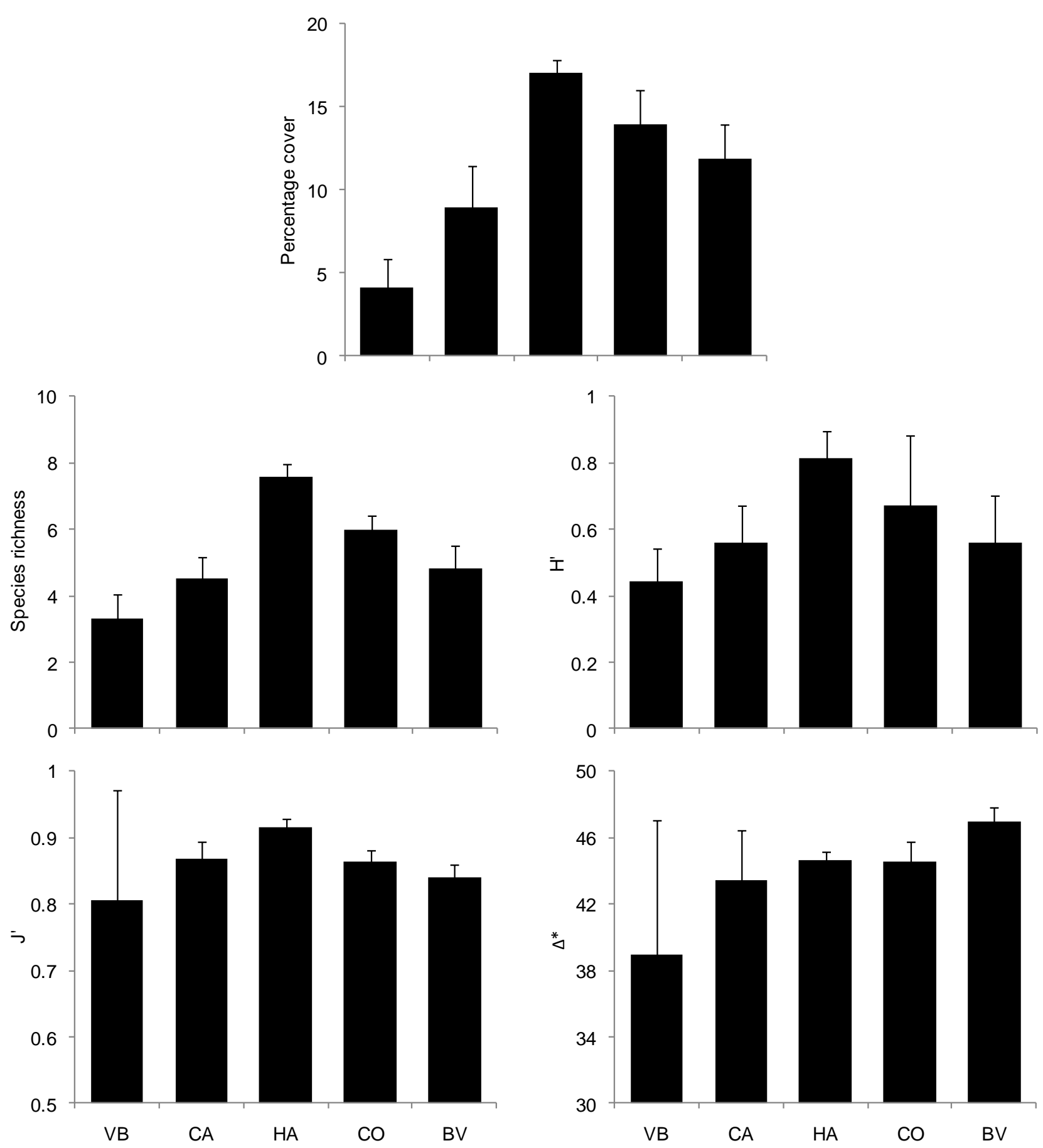

Figure 4. Ecological indices by site reefs outside PNAC (average \pm SE). Key for reefs: VB=Villa Blanca, $\mathrm{CA}=\mathrm{El}$ Castillo, $\mathrm{HA}=$ Hanan, $\mathrm{CO}=\mathrm{Cocos}, \mathrm{BV}=$ Buenavista. 
Mean species richness was $5.22 \pm 0.33$ species per transect across all sites, and the analysis of variance showed significant differences between sites $\left(\mathrm{F}_{4,22}=6.979, p<0.001\right.$; Figure 4). Hanan had the highest average number of species per transect, with $7.60 \pm 0.40 \mathrm{spp}$, while Villa Blanca had the lowest, as in some cases there was only one species seen along the entire transect. There were significant differences between Hanan and the rest of the reefs, with the exception of Los Cocos, which was also statistically different from Villa Blanca.

The diversity index indicated that the average value for corals of the northeastern and northwestern sections of Cozumel was $0.60 \pm 0.02$ decits/ind and the sites varied statistically $(\mathrm{K}-\mathrm{W}=14.154, p=0.006$, $\mathrm{N}=27$; Figure 4). Hanan had significant differences from all other reefs and was the most diverse, with a value of $0.80 \pm 0.02$ decits/ind, and Villa Blanca was again the site with less ecological complexity $\left(\mathrm{H}^{\prime}=\right.$ $0.44 \pm 0.10$ decits/ind). For $\mathrm{J}^{\prime}$, the general average was $0.86 \pm 0.03$ and the index showed statistical differences between reefs too $(\mathrm{H}=9.541, p=0.048, \mathrm{~N}=27$; Figure 4$)$, with Hanan being significantly more uniform than Buenavista and Los Cocos. Finally, average $\Delta^{*}$ was $44.05 \pm 1.83$ units in the entire study zone, but there were no significant differences among reefs $(\mathrm{H}=4.61, p=0.329, \mathrm{~N}=27$; Figure 4). Notwithstanding, there was a small but non-significant positive trend in taxonomic distinctness from north to south, where Buenavista had the highest values with $47.53 \pm 0.80$, and El Castillo the lowest ones.

\section{Between-Zone Comparison}

The comparative analysis of coral cover data presented in this study, and those from Millet-Encalada et al. (2007) for reefs located inside the PNAC (Table 2), indicated that coral abundance did not present significant differences between regions, although the reefs outside the protected area had slightly higher values (Figure 5). In a similar manner, none of the remaining ecological community indices showed significant differences between areas (Figure 5). However, in a purely descriptive manner, it was observed that species richness was higher outside the PNAC, that the diversity was practically identical in both areas, and that evenness and taxonomic distinctness tended to be higher inside the protected area.

Table 2. Results of the Student $t$ test comparing community indices of reefs inside and outside PNAC. In all cases, 62 degrees of freedom.

\begin{tabular}{lccccc}
\hline & Coral cover & S & H' & J' & $\Delta^{*}$ \\
\hline Student t & 0.62 & 0.25 & 0.03 & 0.59 & 1.12 \\
$p$ & 0.53 & 0.79 & 0.97 & 0.55 & 0.25 \\
\hline
\end{tabular}

In addition, the comparison inside vs. outside the PNAC, via nMDS, did not indicate specific groupings due to the high degree of similarity in the species composition among transects. However the results evidenced that sites inside the park form a relatively well defined group in the central area of the graph (Figure 6).

Considering that Villa Blanca might present different characteristics by being located in western Cozumel, we repeated the comparison focusing only in the PNAC reefs and those of the eastern coast. The results were statistically congruent, this is, there were no significant differences in any ecological index, except in the case of coral cover, which was higher inside the park that outside of it $(\mathrm{t} 64=2.38, p=$ $0.02)$. 

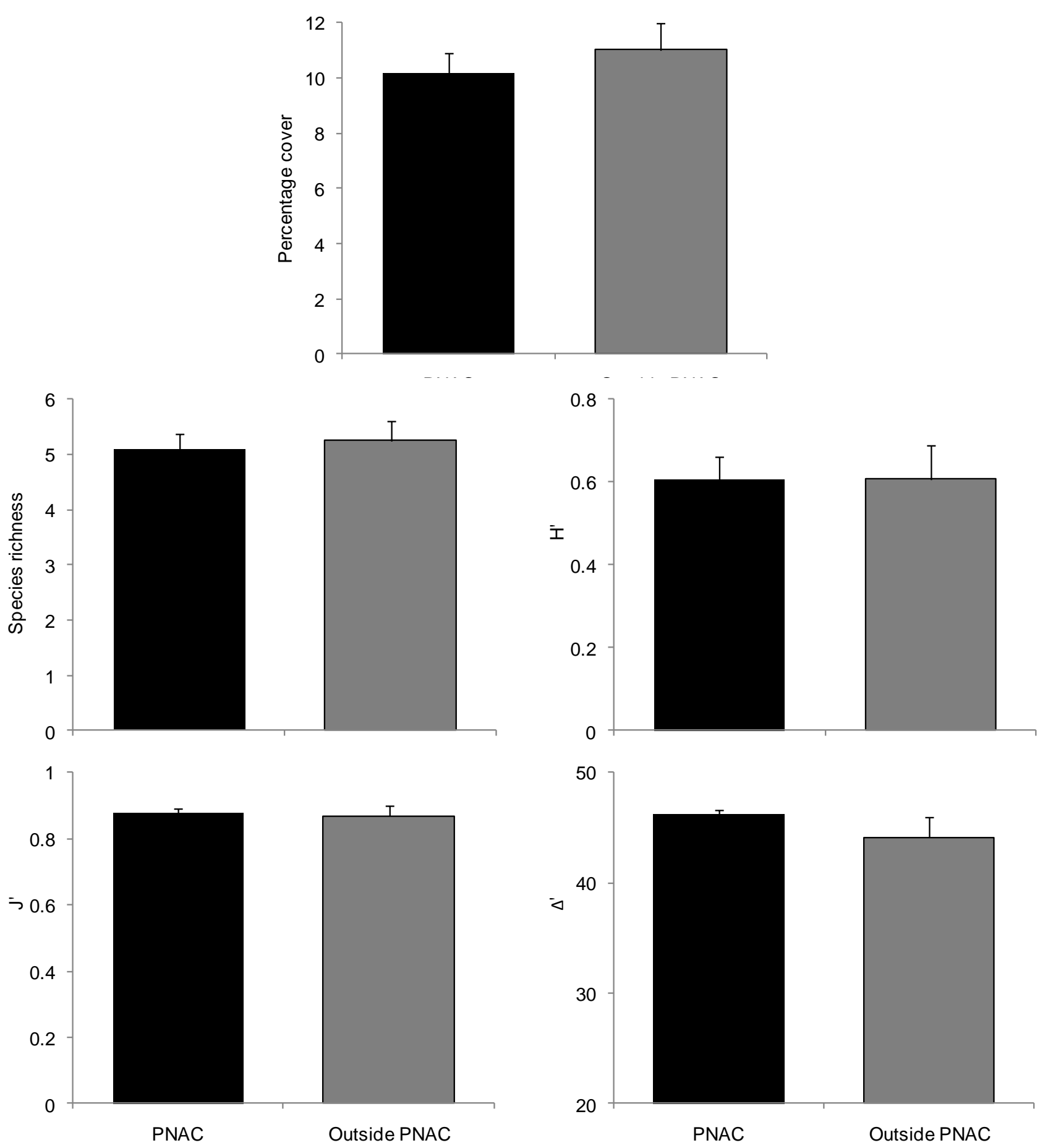

Figure 5. Comparison of community structure of reefs inside (black bars) and outside (gray bars) PNAC. 


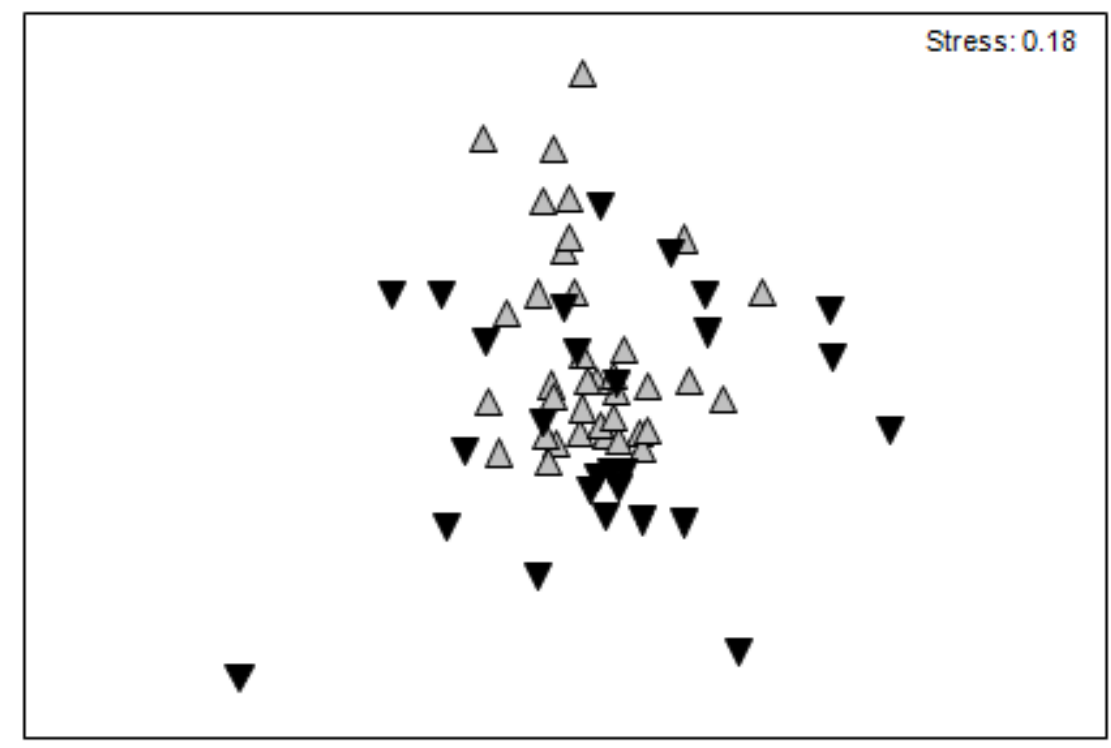

Figure 6. Non metric dimensional scaling of reefs inside (gray triangles) and outside (black triangles) PNAC, constructed with Euclidian distance and the UPGMA algorithm.

\section{DISCUSSION}

Fifty-four species of zooxanthellate corals belonging to 24 genera and 10 families have been recorded in Cozumel so far (Millet-Encalada et al. 2007), and there are no endemic taxa. Comparing these figures to the 65 species known for the western Caribbean (Beltrán-Torres and Carricart-Ganivet, 1999; Cairns, 2000; Miloslavich et al., 2010), and the known richness and composition in other areas such as Cuba (55 especies; Ferrer-González, 2004), Roatán, Honduras (35), the Cayman Islands (44; Fenner, 1993), Belize (51; Cairns, 1982; Fenner, 1999), the Gulf of Mexico (41; Beltrán-Torres and Carricart-Ganivet, 1999), and Guatemala (27; Fonseca and Arrivillaga, 2003), it can be concluded that the coral community of Cozumel is typical of the Caribbean region and has great similarity in species composition with other areas. In addition, during the present study, no new records of corals were made, a fact that denotes the high level of understanding and knowledge already in existence with regard to the coral composition of the island.

Analyzing the records for Cozumel based on the most recent community study (Millet-Encalada et al., 2007), it is observed that Eusmilia fastigiata, Isophyllastrea rigida and Dendrogyra cilindrus continually sighted within the PNAC are not found in the external zone, while Isophyllia sinuosa, Porites colonensis, Diploria clivosa and Acropora palmata were not registered within the park (Table 1). This difference is relevant and indicates that the latter corals tend to distribute in sites with intense wave regimens, as is the case with the windward side of the island where conditions can be strong and variable (García-Beltrán and Loreto-Viruel, 1997). The same circumstance apparently favors the presence of Acropora palmata populations along the eastern coast of the island (García-Beltrán and Loreto-Viruel, 1997), as well as at Punta Sur (inside the limits of the PNAC: personal observation). Although this species was registered in a low percentage in the samples (Table 1), it is very important as it is critically endangered (Carpenter et al., 2008) and has been officially protected in Mexico since almost 15 years ago (Anonymous, 1998).

The low incidence of Acropora at Cozumel is not a recent phenomenon but has been reported since the 1980s, and is probably due to the low hydrodynamic levels that exist on the leeward side of the island, 
a lack of exuberant growth of the reef crest, and the fact that most reefs are found deeper than the known limits of its distribution (Fenner, 1988; Jordán, 1988). Furthermore, it is possible that the well documented massive coral death resulting from white band disease in previous decades has also influenced this situation (Aronson et al., 1998; Aronson and Precht, 2001), and finally, there is evidence of the physical destruction of colonies caused by hurricanes at several occasions (Jordán-Dalhgren and Rodríguez-Martínez, 2003).

In relation to coral coverage, the figures presented in this study for the eastern and northwestern coasts of Cozumel (11.02 $\pm 1.07 \%$ in average) were very low compared to that presented in previous surveys around the island, as Fenner (1988) and Muckelbauer (1990) reported 33.5\% and 25.2\% cover, respectively, for the southwestern coast, and . García-Beltrán and Loreto-Viruel (1997) found an average cover of $18.3 \%$ at the shelf edge in the windward side. According to our observations, the main cause of the observed low coral abundance everywhere at Cozumel in 2005 was the influence of hurricanes "Emily" and "Wilma" that affected the location in the months of July and November, respectively, and caused a severe coral mortality (Álvarez-Filip and Gil, 2006, Millet-Encalada et al., 2007; Álvarez-Filip et al 2009).

The average Shannon's diversity index value obtained in the study area was $0.60 \pm 0.02$ decits/ind, which is relatively low compared to that reported for the western edge of Cozumel ( 0.77 to 0.78 decits/ind; Fenner 1988, Muckelbauer 1990) and for continental reefs of the northern Yucatán Peninsula (0.69; Jordán et al., 1981). This low diversity indicates that a small number of species dominate the community, as can be seen in Figure 3, where Agaricia agaricites represents $28 \%$ of the total coverage.

The ecological indices indicated that Hanan reef is the richest and most diverse of all studied reefs in the eastern portion of Cozumel (Figure 6). These data agree with other reports that remark its significantly high coral cover, describe its good physical development and mention the presence of a conspicuous system of development of spur and grooves (García-Beltrán and Loreto-Viruel, 1997). Such formations are common in the Caribbean and favor the presence of corals as well as the complexity of the reef framework by means of providing protection against the pounding of the waves (Jordán et al., 1981). Considering the presence of Acropora in the section of "microatolls" of this location, and the relatively good condition of the reefs, Hanan must be considered as a hot spot for conservation at Cozumel of high priority for conservation, and should have priority for its inclusion in the PNAC.

In complete contrast to Hanan is the case of Villa Blanca, a reef that a decade ago had $44 \%$ coverage of scleractinian corals (García-Beltrán and Loreto-Viruel, 1997); that figure is an order of magnitude higher than the one found in the present study (4\%). This drastic decline may be influenced by the reef's close proximity to the coast, thereby making it susceptible to the negative effects that have been brought about by coastal development in the region, such as an increase in pollutants and nutrients. Also, this reef is subject of frequent use by tourists that participate in diverse recreational activities (principally snorkeling and scuba diving), and by locals who participate in fishing activities. As the zone is not subject to official protection, the deterioration has been significant.

The comparison of coral communities inside and outside of the protected zone provided very interesting results. As observed (Figs. 9 and 10), these regions are similar in all the descriptive indices evaluated, although possessing certain differences in composition. This similarity does not support the idea that more diverse reefs are found facing leeward as stated by Fenner (1988) and Jordán (1988), but coincides with more recent data that reports windward reefs as sites with the same or higher coral development than more sheltered sites (Jordán and Martin, 1988; García-Beltrán and Loreto-Viruel, 1997). On the other hand, the only ecological indicator that showed some change was coral cover (higher outside of PNAC), and that occurred when Villa Blanca reef (the one in worst condition) was subtracted from the analysis. The full information makes us suggest that as most windward reefs are somewhat inaccessible for tourism, therefore anthropogenic pressure is minimal when compared with the situation on the west side of the island, where thousands of divers explore the reefs every day (Palafox et al., 2009). From this observation we emphasized the importance of the conservation of the reef ecosystems found outside the PNAC, in order to maintain them in the best possible fashion.

The noticeable homogeneity in community structure in Cozumel reefs may be a transient phenomenon, an anomaly that may reflect the state of the communities after major perturbations that 
affected the whole island (Alvarez-Filip and Gil, 2006). The intense impact of the consecutive hurricanes of the 2005 season clearly modified the conformation of the communities by damaging colonies that are structurally susceptible like those of Porites porites and Agaricia spp. (Alvarez-Filip et al., 2009), and it is not surprising that the same genera were reported as among the species most damaged after hurricane "Gilbert" (Fenner, 1991).

The average evenness found in all reefs of this study was $0.86 \pm 0.01$ and is remarkably higher than that reported from Cozumel by Fenner (1988) with a value of 0.61, and by García-Beltrán and LoretoViruel (1997) with a value of 0.77. Likewise, other regions of the Mexican Caribbean also have lower values, never above 0.75 units (Jordán et al., 1981). The high values generated for Pielou's index in the present study demonstrate that abundance was divided proportionally among species, presumably the result of hurricanes triggering the loss of many colonies of dominant species and leaving relatively homogenous coralline communities in terms of the number of species (Álvarez-Filip and Gil, 2006). The fact that $\mathrm{J}^{\prime}$ was the only index that demonstrated significant differences between the eastern and western zones of the island, and that had the highest value within the PNAC, may reflect the magnitude of these particularly intense perturbations for the protected zone, as these perturbations were able to change the composition of coralline species to a state of lower diversity during a very short time span.

\section{CONCLUSIONS}

The coral conformation of Cozumel reefs situated outside the marine protected area shows a composition of species typical of most reef communities of the western Caribbean, with a few species in high frequency and abundance, and most relatively rare. There were no significant differences between reefs inside and outside the protected area, a pattern that differed from that reported in previous studies. Possibly, the homogeneity in reef ecological structure resulted from a combined effect of human use (high in PNAC reefs, low outside of the park), and the impacts derived from hurricanes "Emily" and "Wilma" in 2005. Because of the current similarity of reefs all over Cozumel Island, we strongly suggest that local authorities should dedicate more effort to the conservation of reefs in the eastern coast of the island, as some of them (especially Hanan) are very well developed and house species of particular interest such as Acropora spp.

\section{ACKNOWLEDGMENTS}

The authors thank Ricardo Gomez Lozano (Director; Cozumel Reefs National Park) and the park staff, who were instrumental in order to conduct field work in the area. This study was partially funded by the PNAC and Comisión Nacional para el Conocimiento y Uso de la Biodiversidad, project DM007 (to H.R.B.). During the preparation of the paper, L.A.F. was grantee of scholarships from CONACYT (171864) and SEP. The manuscript was kindly proofread by Nell Hamilton (Simon Fraser University). 


\section{REFERENCES}

Almada-Villela, P.C., P.F. Sale, G. Gold-Bouchot, and B. Kjerfve. 2003. Manual de métodos para el programa de monitoreo sinóptico del Sistema Arrecifal Mesoamericano. Belize City:

Mesoamerican Barrier Reef System.

Álvarez-Filip, L., and I. Gil. 2006. Effects of hurricanes Emily and Wilma on coral reefs in Cozumel, México. Coral Reefs, 25:583.

Álvarez-Filip, L., M. Millet-Encalada, and H. Reyes-Bonilla. 2009. Impact of hurricanes Emily and Wilma on the coral community of Cozumel island, Mexico. Bulletin of Marine Science, 84:295-306.

Anonymous. 1996. Declaración del Area Natural Protegida Parque Marino Nacional Arrecife de Cozumel. Diario Oficial de la Federación. Viernes 19 de mayo de 1996.

-1998. Programa de manejo Parque Marino Nacional Arrecifes de Cozumel. Mexico City: Instituto Nacional de Ecología.

Aronson, R.B., and W.F. Precht. 2001. White-band disease and the changing face of Caribbean coral reefs. Hydrobiologia, 460:25-38.

Aronson, R.B., W.F. Precht, and I.G. Macintyre. 1998. Extrinsic control of species replacement on a Holocene reef in Belize: The role of coral disease. Coral Reefs, 17:223-230.

Arriaga-Carrera, L., E. Vázquez-Domínguez, J. González-Cano, R. Jiménez-Rosenberg, E. Muñoz-López, and V. Aguilar-Sierra. 1998. Regiones prioritarias marinas de México. México: CONABIO.

Beltrán-Torres, A.U., and J.P. Carricart-Ganivet. 1999. Lista revisada y clave para los corales pétreos zooxantelados (Hydrozoa: Milleporina; Anthozoa: Scleractinia) del Atlántico mexicano. Revista de Biología Tropical, 47:813-829.

Boyd, D.W, L.S. Kornicker, and R. Rezak. 1963. Coralline algae microatolls near Cozumel Island, México. Contributions to Geology, 2:105-108.

Cairns, S.D. 1982. "Stony corals (Cnidaria: Hydrozoa, Scleractinia) of Carrie Bow Cay, Belize." In The Atlantic Barrier Reef Ecosystem at Carrie Bow Bay, Belize, I: Structure and Communities, ed. K. Rützler and I. Macintyre, pp. 271-302. Smithsonian Contributions to the Marine Sciences, No. 12. Washington, DC: Smithsonian Institution Scholarly Press.

2000. A revision of the shallow-water azooxanthellate Scleractinia of the western Atlantic. Studies on the Natural History of the Caribbean Region, 75:1-231.

Cetina, P., O. Candela, J. Sheinbaum, J. Ochoa, and A. Badan. 2006. Circulation along the Mexican Caribbean coast. Journal of Geophysical Research, 111 C08021:1-19.

Chávez, E.A. 1997. Sampling design for the study of Yucatan reefs, Northwestern Caribbean. Proceedings of the 8th International Coral Reef Symposium 2:1465-1470.

Clarke, K.R., and R.M. Warwick. 2001. Change in marine communities: An approach to statistical analysis and interpretation. 2nd Ed. Plymouth, England: PRIMER-E Ltd.

Díaz-Ruiz, S., A. Aguirre-León, and J.E. Arias-González. 1998. Habitat interdependence in coral reef ecosystems: A case study in a Mexican Caribbean reef. Aquatic Ecosystem Health and Management, 1:387-397.

Fenner, D.P. 1988. Some leeward reefs and corals of Cozumel, México. Bulletin of Marine Science, 42:133-144.

1991. Effects of hurricane Gilbert on coral reefs, fishes and sponges at Cozumel, México. Bulletin of Marine Science, 48:719-730.

1993. Species distinctions among several Caribbean stony corals. Bulletin of Marine Science, 53:1099-1116.

1999. New observations of the stony coral (Scleractinia, Milleporidae and Stylasteridae) species of Belize (Central America) and Cozumel (Mexico). Bulletin of Marine Science, 64:143-154.

Ferrer-González, S. 2004. Corales pétreos, jardines sumergidos de Cuba. España: Digital Da Vinci.

Fonseca, A.C., and A. Arrivillaga. 2003. Coral reefs of Guatemala. In Latin American coral reefs, ed. J. Cortés, pp. 159-170. Amsterdam: Elsevier.

García-Beltrán, G., and R.M. Loreto-Viruel. 1997. Caracterización de los arrecifes coralinos de Isla Cozumel, Quintana Roo, México. Amigos de Sian Ka’an Serie de Documentos, 6:3-59. 
Gutiérrez-Carbonell D., M. Lara-Pérez Soto, C. Padilla-Souza, J. Pizaña-Alonso, G. García-Beltrán, R.M. Loreto-Viruel, and T. Camarena-Luhrs. 1995. Caracterización de los arrecifes coralinos en el corredor “Cancún-Tulum”, Quintana Roo, México. Amigos de Sian Ka'an Serie de Documentos, 4:3-39.

Humann, P. 2002. Reef coral identification. Florida Caribbean Bahamas. 2nd Ed. Jacksonville, Fla.: New World Publications.

Jordán, E. 1988. Arrecifes profundos en la Isla de Cozumel, México. Anales del Instituto de Ciencias del Mar y Limnología, UNAM, 15:195-208.

Jordán, E, and E. Martin. 1988. Chinchorro: Morphology and composition of a Caribbean Atoll. Atoll Research Bulletin 310:1-20.

Jordán, E., M. Merino, O. Moreno, and E. Martín. 1981. Community structure of coral reefs in the Mexican Caribbean. Proceedings of the 4th International Coral Reef Symposium, Manila 2:303-308.

Jordán-Dahlgren, E. 1989. Efecto de la morfología del sustrato en el desarrollo de la comunidad coralina. Anales del Instituto de Ciencias del Mar y Limnología, UNAM, 16:105-118.

Jordán-Dahlgren, E., and R. Rodríguez-Martínez. 2003. The Atlantic coral reefs of México. In Latin American coral reefs, ed. J. Cortés, pp. 131-158. Amsterdam: Elsevier.

Magurran, A. E. 2004. Measuring biological diversity. Oxford: Blackwell.

Millet-Encalada, M., L. Álvarez-Filip, and H. Reyes-Bonilla. 2007. Estructura comunitaria de corales escleractinios en el Parque Nacional Arrecifes de Cozumel. In Biodiversidad acuática de la Isla de Cozumel, ed. L.M. Mejía-Ortíz, pp. 327-347. Mexico City: Plaza y Valdés.

Muckelbauer, G. 1990. The shelf of Cozumel, México: Topography and organisms. Facies, 23:185-240.

Muñoz-Chaguín, R.F. 1997. Coral transplantation program in the Paraiso coral reef, Cozumel Island, Mexico. Proceedings of 8th International Coral Reef Symposium, Panamá 2:2075-2078.

Ortiz-Lozano, L., A. Granados-Barba, V. Solís-Weiss, and M.A. García-Salgado. 2005. Environmental evaluation and development problems of the Mexican Coastal Zone. Ocean and Coastal Management, 48:161-176.

Palafox-Muñoz, A., R. Segrado-Pavón, and L. Zizumbo-Villarreal. 2009. Rehabilitación turística y capacidad de carga en Cozumel: propuesta metodológica. Revista de la Red Iberoamericana de Economía Ecológica, 11:53-63.

Rützler, K., and I.G. Macintyre. 1982. The Atlantic barrier reef ecosystem at Carrie Bow Cay, Belize, 1: Structure and Communities. Smithsonian Contributions to the Marine Sciences, No. 12. Washington, DC: Smithsonian Institution Scholarly Press.

Sokal, R.R., and F.J. Rohlf. 1995. Biometry. 3rd Ed. New York: Freeman.

Spalding, M.D. 2004. A guide to the coral reefs of the Caribbean. Berkeley, Calif.: University of California Press.

Steneck, R.S., P.A. Kramer, and R.M. Loreto. 2003. The Caribbean's western-most algal ridges in Cozumel, Mexico. Coral Reefs, 22:27-28.

Veron, J.E.N. 2000. Corals of the World. Volumes 1-3. Townsville, Australia: Australian Institute of Marine Science.

Zar, J.H. 2009. Biostatistical analysis. Englewood Cliffs, N.J.: Prentice-Hall. 